\title{
PLAY IN A
}

\section{SARTREAN FEMINIST ETHICS ${ }^{1}$}

("Play in a Sartrean Feminist Ethics" is a part of A Feminist Eshics of Freedom, forthcoming from Rowman \& Littlefield Publishers, reprinted by permission.)

A feminist existentialist ethics, such as I am proposing ${ }^{2}$ here, will agree with Jean-Paul Sartre's moral judgment condemning the denial of freedom while at the same time affirming that each person must choose her or his own values. The claim that each must choose values, however, is not unproblematic. Inherent in this claim is a relativism of values, frequently challenged by those who claim that the recognition of values as arbitrary and unjustifiable renders difficult and highly unlikely-or impossible-any individual's continued adherence to particularly demanding moralities. Even sympathetic critics have expressed fear that Sartre's and Simone de Beauvoir's "willingness to put their lives and honor on the line in support of human dignity seems to bear witness to the very spirit of seriousness they so scornfully reject. ${ }^{n 3}$

Equally problematic is the recognition of futility. For Sartre, futility is an inevitable aspect of the human situation. For others, like Alison Jaggar, futility is recognized when she points to ". . . the problem of discovering viable ways of living . . . with contradictions that are presently ineradicable." The difficulty

\footnotetext{
'As part of a larger manuscript, this paper owes much to the careful readings, critiques, and editing of Diane L. Fowlkes and Albert C. Skaggs. In addition, Olga Skorapa was extremely helpful when I consulted her about the directions I was taking the concept of play.

2 This is part of a larger project, a book-length manuscript, tentatively titled "A Feminist Ethics of Freedom."

3Thomas C. Anderson, The Foundation and Structure of Sartrean Exhics (Lawrence: The Regents Press of Kansas, 1979), p. 149.
} 
is created by the fact that feminist women must live and act in an already constructed world with intricate power relations: "When racism, capitalism and male dominance are seen to penetrate political organizations, the home and even the bedroom, socialist feminist women are left with no place of refuge from the struggle. They are always on the front lines." Since these contradictions are at least for now unresolvable, requiring as they do fundamental changes in the structure of society, Jaggar concludes that feminists ". . . must discover how to live with these contradictions in such a way as to find not despair and defeat, but joy and strength in the struggle against them. ${ }^{n 4}$

My belief that play may help to provide the needed answers had its inspiration in two sources. One was Sartre's ethics, in which play is seen as a way of resolving problems resulting from the choice of values in a situation where there will always be ambiguity and failure. The other inspiration was references to play and playfulness in writings by feminist theorists. Sometimes these writings refer to play as a revolutionary strategy. Sometimes they refer to play or playfulness as a joyful celebration of freedom and love, however circumscribed these may be by oppressive structures and by threats of violence. Frequently they suggest something similar to Sartre's use of play.

Like Sartre, Sarah Hoagland recognizes the ability to embrace ambiguity as essential to morality; and, like Sartre, she proposes that playfulness makes such embrace possible. She cites Maria Lugones's idea of "playful world travel" as a way to "learn to love cross-culturally and cross-racially." Hoagland describes this playful world travel as "the ability to suspend not belief, but disbelief. It is not our belief so much as our disbelief that leads us to discount others and keeps us loyal to patriarchal perception. ${ }^{m 5}$ Here play seems both a revolutionary strategy and a way to live with relativism. This dual role also is ascribed to play in Annette Kolodny's "playful pluralism, " ". . . responsive to the possibilities of multiple critical schools and methods, but captive of none,

\footnotetext{
${ }^{4}$ Alison Jaggar, Feminist Politics and Human Nature (Totowa, NJ: Rowman \& Allanheld, 1983), pp.345-46.

${ }^{5}$ Sarah Lucia Hoagland, Lesbian Ethics (Palo Alto, CA: Institute of Lesbian Studies, 1988), p. 242.
} 
recognizing that the many tools needed for our analysis will necessarily be largely inherited and only partly of our own making. " "6

In this paper, then, I examine first the role play can serve in constructing resolutions to problems of both relativism and futility. In these resolutions, I draw heavily from Sartre's work and from my own earlier analysis of his ethics. ${ }^{7}$ Finally, with help from many disparate sources, I explore the revolutionary possibilities of play.

\section{Play and the Spirit of Seriousness}

Sartre contrasts play with the "spirit of seriousness" in which the "serious man" tries to give himself "the type of existence of the rock, the consistency, the inertia, the opacity of being-in-the-midst-of-the-world. " One who is serious, Sartre says, is concerned with consequences: "[A]t bottom [he] is hiding from himself the consciousness of his freedom; he is in bad faith and his bad faith aims at presenting himself to his own eyes as a consequence; everything is a consequence for him, and there is never any beginning. That is why he is so concerned with the consequences of his acts. ${ }^{\mathrm{B}}$

Play is concerned with consequences, too, but in a different way. The serious person sees consequences as beyond her or his control; indeed, such an individual sees herself or himself as a consequence of other causes. In play, on the other hand, consequences are viewed as the result of free activity. Play is "an activity of which man is the first origin, for which man himself sets the rules, and which has no consequences except according to the rules posited!" Play begins "[a]s soon as a man apprehends himself as free and wishes to use his freedom, a freedom, by the way, which could just as well be his anguish,

\footnotetext{
${ }^{6}$ Annette Kolodny, "Dancing Through the Minefield: Some observations on the Theory, Practice, and Politics of a Feminist Literary Criticism," Women and Values: Readings in Recent Feminist Philosophy, ed. Marilyn Pearsall (Belmont, CA: Wadsworth Publishing Co., 1986), p. 252.
}

7See Linda A. Bell, Sartre's Ethics of Auchenticity (Tuscaloosa: The University of Alabama Press, 1989).

${ }^{8}$ Jean-Paul Sartre, Being and Nothingness, trans. Hazel E. Barnes (New York: The Philosophica! Library, 1956), p. 580. 
then his activity is play. The first principle of play is man himself; through it he escapes his natural nature; he himself sets the value and rules which he has established and defined." 9

In Cahiers pour une morale, Sartre presents play as a break from the spirit of seriousness and as vitally connected with authenticity. In discussing risk, he says,

I don't prove my freedom only by the pure subordination of the exterior world; I prove it also in agreeing to struggle against it. . . At the same time the challenge is play: it is a nupture with the spirit of seriousness, [it is] expenditure, annihilation, passage to the festive side. The festival in effect is liberation from the spirit of seriousness, the expenditure of economics, the ruin of hierarchy, and the absorption of the other by the Same, of the objective by intersubjectivity, of onder by disonder. Thus the apocalypse will be one of the extreme types of human relations. ${ }^{10}$

Such play is not a leisure-time activity. Here Sartre differs from Johan Huizinga's proposal in the latter's famous study of play. ${ }^{11}$ Herbert Marcuse is closer to Sartre's understanding of play when he describes it as "the play of life itself, beyond want and external compulsion, " not because wealth and leisure have freed those who play from constraint, but rather because the "constraint [which] is the reality . . . 'loses its seriousness' and . . . its necessity 'becomes light." "This play changes human activity into "display-the free manifestation of potentialities. ${ }^{112}$

Sartre's play is also quite different from the contest-play of which Huizinga writes. While "the primary thing" of Huizinga's contest-play is to excel over others, Sartre's play seems compatible with non-competitive behavior. However, they would agree that if and when playful activity involves

${ }^{9}$ lbid., pp. 580-81.

${ }^{10}$ Sartre, Cahiers pour une morale (Paris: Gallimard, 1983), p. 388. This and all other citations of Cahiers are my own translations.

"Johan Huizinga, Homo Ludens: A Study of the Play-element in Culture (Boston: Beacon Press, 1950), p. 8.

${ }^{12}$ Herbert Marcuse, Eros and Civilization: A Philosophical Inquiry into Freud (Boston: Beacon Press, 1955), pp. 187, 190. 
competitiveness, this competitiveness is not, as Huizinga says, "in the first place a desire for power or a will to dominate. ${ }^{n 13}$

\section{Play as Partial Resolution to the Problems of Relativism}

On the basis of these statements about play, along with a little help from observations about ordinary play, we can construct resolutions to the problems of relativism and futility. These resolutions must deal, first, with both Sartre's denial of any preexisting justifications for our action and his affirmation of the necessity of creating and sustaining in existence our own values. Second, the resolutions must support continued activity even in the light of full recognition of a gap between our goals and our accomplishments that, given human freedom and reality, even God could not bridge.

In play, we create without being bound by any preexisting values, prescriptions, and proscriptions. Children at play may create characters, dialogues, situations, and actions. While many of these may merely mirror the scenes they have witnessed, some are quite different and even reflect values that differ considerably from those taught by and evinced in the lives of parents and teachers. Adults invent games and sustain them in existence, for example, by freely following the rules they have created, thus "playing the game."

Sartre's authentic individuals must create their own values through their actions; moreover, they must recognize that their choices of these values are not necessary and are neither supported nor justified by anything whatsoever. Like one who invents a game, those who are authentic know they could have chosen differently; but, like the creator of the game, they in fact made a certain choice and not another. To say that they chose is to say that they brought certain values and not others into being. This does not mean, however, that the decisions are irrevocable. Rather, these individuals remain free to revoke the chosen values as values. What they cannot do is to abolish the fact of their having chosen these values.

Whereas both the creator of the game and the authentic individual are thereafter free to alter or reject their game and chosen value, respectively, both individuals may choose not to alter or reject and instead continue to act in accordance with their choices. There is no gap, much less an unbridgeable one,

\footnotetext{
${ }^{13}$ Huizinga, Homo Ludens, p. 50.
} 
between the choice of a value and action in accordance with the choice. Choosing and acting are simply not separable. To assume one can choose without acting or act without choosing, or avoid both choosing and acting, certainly is to assume a position foreign to Sartre's. To choose a value is to act, in appropriate circumstances, on that choice; similarly, to act is to make value choices. If Sartre is correct, one can avoid neither choice nor action. Not to choose is itself a choice, and, generally, not to act is itself an action.

If the problem is that of sustaining one's commitment, particularly to demanding values, in the face of the realization that one's chosen values have no external, objective justification, play offers a resolution. Although this may be a more empirical and less properly philosophical problem, at least an analogy with other forms of play suggests that the psychological problem may not be as serious as some believe. After all, countless individuals have developed and participated in games that demand extraordinary preparation, skill, and exertion. Surely some of these individuals were aware that there were other, less demanding possibilities no more (and, of course, no less) objectively warranted or justified.

The very question "Why would an individual continue to affirm previously chosen values?" either ignores the fact that any other values would be equally arbitrary or it assumes that we are free to cease choosing and acting. We may choose to end a game or discontinue a project. We may even do so for what we consider good and compelling reasons. If, however, we recognize that there are no such reasons for continuing the game or the project on which we have been working, surely this, in itself, is insufficient reason to drop it. To play this objectivist game of demanding good and compelling reasons, and to do so evenhandedly, requires that there be sufficient reason for whatever we do-even if we discontinue the project. Too many fail to recognize that for every "Why?" there is a "Why not?" that is just as difficult to answer. Many a project may be completed for no better reason than that it was initiated.

Does this invalidate commitment, as critics have affirmed? Maurice Merleau-Ponty's challenge seems especially serious: "From the single fact that it is a question of committing oneself, that the prisoner is also his own jailer, it is clear that one will never have other bonds than those one currently gives 
oneself and that one never will be committed. ${ }^{14}$ This challenge is partially correct: one is never completely bound by what one has chosen or done. One can always free oneself from the direction specified by past choices and actions. However, to the extent Merleau-Ponty is correct, what he says indicates more an advantage than a disadvantage in the view of freedom to which he is objecting. His challenge becomes a significant objection to the possibility of commitment only when it is conjoined with his view of Sartrean freedom as the "pure power of doing or not doing, a power that fragments freedom into so many instants, ... the freedom to judge, which even slaves in chains have. "15 Yet this is a view of freedom Sartre, in his 1946 essay "Materialism and Revolution," quite rightly rejects as a "pure idealistic hoax." 16

From Sartre's analysis of freedom and reflection, I conclude that commitment is meaningful at each of two levels. First, in choosing, one may attempt to engage the future, to bind future decisions by making conflicting decisions as difficult as possible. This level of commitment is paralleled in Sartre's later writing by what the group does in its attempt to restrict or bind in advance, by promises and by terror, the freedom of its members. This level of commitment seems to be a vital aspect of many if not all choices inasmuch as many acts of will involve at least some reference to a prolongation into the future of what is chosen. As de Beauvoir says, "I can not genuinely desire an end today without desiring it through my whole existence, insofar as it is the future of this present moment and insofar as it is the surpassed past of days to come. To will is to engage myself to persevere in my will [emphasis mine]. "17

The practical import of this feature of will is that in acting one always finds oneself bound to some extent by past actions and that one acts in ways that deliberately bind as far as possible one's own future actions. While one always

\footnotetext{
14 Maurice Merleau-Ponty, "Sartre and Ultrabolshevism," Adventures of the Dialectic, trans. Joseph Bien (Evanston, IL: Northwestern University Press, 1973), p. 195.

${ }^{15}$ Ibid., p. 196.

${ }^{16}$ Sartre, "Materialism and Revolution," Literary and Philosophical Essays, trans. Annette Michelson (New York: Collier Books, 1962), p. 237.

${ }^{17}$ Simone de Beauvoir, The Ethics of Ambiguity, trans. Bernard Frechtman (New York: The Citadel Press, 1964), p. 27.
} 
remains free to "break" these bonds and to launch a new project that undermines past projects, this change of direction is not easy, given the momentum and all the "reasons" one has created for oneself by past choices.

Second, one's fundamental choice of self to a considerable extent binds one's future choices. If this choice is one that values freedom, it requires an ensemble of projects and motivations that will call for actions in support of freedom. Thus, one is committed to such actions and to the rejection of actions which limit freedom. The fact that one can call into question one's fundamental choice and that "conversion" is possible does not mean that doing so is easy nor does it mean that the recognition of this possibility precipitates one into a limbo of paralysis. It does mean, however, that there is a level of freedom underlying all that an individual can or does count as a reason for choice.

Play can help us understand and live with this fundamental choice, whether it is the original making of the choice, if there be such, or the continuing adherence to the particular choice, or a conversion from that choice. To some extent, one's fundamental choice is like one's decision to play a game; once made, the choice, like the decision to play the game, gives the individual who so chose good and compelling reasons to act in a particular way or to execute one move rather than another. Yet the playful spirit out of which came the decision to play is not itself provided thereby with similarly good and compelling reasons for that decision. In fact, the decision itself may have no adequate motivation at all; but such a consideration will not dampen the spirits of the player. After all, precisely by choosing to play, the player has suspended the rules of the serious, rules which require such justification for any choice one may make.

\section{Play as Resolution to Problem of Futility}

The problem of futility is, I believe, a more difficult one to resolve and its resolution more centrally involves play. By examining games, we have seen that such play either exposes implausible assumptions of, or resolves problems allegedly confronting, the relativism espoused by Sartre. In a game, a player participates as if the rules or values of the game have some sort of necessary, objective reality and validity. At the same time, as long as players are playing and not so caught up in winning that they mistake the game for something else, they recognize that these rules and values have no such necessity or objectivity. 
In other words, one who plays avoids the seriousness of those who no longer play. In avoiding this seriousness, such an individual also avoids the serious person's reaction to futility. Even inescapable futility is not an insurmountable problem for those who play. In play, not only may we spend time and energy to unbalance balanced objects without much likelihood of success, but also we may exert great effort to balance unbalanceable objects and to fill sieves with water.

Does it make sense, however, to place life and honor on the line, as did Sartre and de Beauvoir? Did they, as has been claimed, thereby slip into seriousness? Although people frequently risk their lives in games, we tend to view play as a frivolous activity, to assume that those who risk their lives in play are doing so not for the game but for some reward external to the game itself. With such reasoning, we move into seriousness and thus beg a fundamental question by assuming that there are ready-made values, some of which may warrant the risking of life and some of which do not. More fundamentally, we beg the question Sartre deals with by assuming that an individual's own life is valuable, that only something objectively higher in value could possibly warrant an action that risks that life.

If Sartre is correct, we determine the extent to which our lives are valuable, as well as their value vis-à-vis other values. Even the value of freedom emerges in the context of willing other values, and those values set the parameters for the valuing of freedom; for example, the freedom willed by the lucid daredevil may be part of a short life, but one lived intensely. The values created and sustained in play are not frivolous in comparison with those of the players' lives; values have no existence apart from individual choices. Certainly there is no hierarchy of values independent of such choices. Serious human beings try to convince themselves otherwise, but their consternation over the irrationality of those who play "for keeps" cannot count as a legitimate objection to the unserious play of those who are authentic.

The interesting thing about play as a resolution to the problem of futility is that it changes both the nature and the outcome of the project. Authentic individuals and groups turn to some extent from impossible goals as such to what is within their control. This does not mean that impossible goals will be left behind. It means rather that, for the authentic individual, such ideals become 
regulative. ${ }^{18}$ To take goals as regulative is to take them as guiding behavior but not as depicting goals actually to be realized. Although individuals and groups may be unable evet to achieve the harmony and unity represented by such ideals as God and organism, the ideals nonetheless may guide behavior. Concretely, this would mean that, instead of trying to be, for example, an identity of being-for-others and being-for-self, individuals would strive to be (for themselves) what they appear (to others) and to appear to be (to others) what they are (to themselves). The authentic individual assumes responsibility for and attempts to harmonize as far as possible those disparate aspects of herself or himself while the individual in bad faith tries to unify, to reduce them without remainder to one another, and, failing to unify, then uses the impossibility of such unity as a justification for any and all behavior.

Thus, as long as the city of ends is taken as a non-regulative ideal, that is, as a goal actually to be realized, ethics faces a dilemma. On the one hand, if the goal is not in fact realizable, in other words, if the goal is merely ideal, then, as Sartre says, "hope disappears." On the other hand, if the city of ends is regarded as realizable but only by projecting this possible actualization into some far-distant future, then the end remains beyond and outside the means and potentially able to justify any and all means. It would then lead to "the maxim of violence": "the end justifies the means."

To avoid defeatism and violence, Sartre proposes that the goal must be viewed not "as being by relation to the means in the exteriority of indifference .. . [but rather] as the organic unity of the means. "In other words, such a goal is not "the last link in the causal series A, B, C, D, E, F . . but . . is the organic totality of the operation." Because Sartre's resolution of his antinomy requires that we see the end in the means, and not as totally separate from them, the means will truly be a "prefiguration of a city of ends":

\footnotetext{
${ }^{18}$ Hazel E. Barnes, An Existentialist Ethics, (New York: Vintage Books, 1967), pp. 94-95, offers a similar interpretation of unity or coincidence as a "regulating idea or principle." She recognizes that this move is a Kantian one, since it was Kant who proposed in The Moral Law, trans. H. J. Paton (New York: Barnes \& Noble, Inc., 1963), the way ideas like that of perfection are to serve in morality as regulative ideas. For Kant, however, such ideas were merely empirically impossible, that is, not in fact achievable in a finite time; and, as I have argued elsewhere, he failed to see or be concerned with ways the utilization of such regulative ideas in morality might contribute to and support violence and injustice.
} 
The solution of the antinomy is to not distinguish the end from the means and to treat man as end in the same measure in which I consider him as means, that is to say, to cause him to think himself and to will himself freely as means in the moment to the extent to which I treat him as end and making it known to him that he is absolute end in the decision itself through which he treats himself as means. ${ }^{19}$

Although we continue to be guided by the impossible, such goals should be understood and pursued as regulative, and the concrete aims that we form in their light must take into account circumstances and probabilities. In bad faith,individuals may try to achieve their ultimate goal through magic and incantations like one who faints in fear, thereby magically causing the "disappearance" of the threat. ${ }^{20}$ By fainting, the fearful person relinquishes or denies responsibility for his or her body and its actions and retreats into pure subjectivity. Futility enters into the fainter's behavior but in a way entirely different from the way it did in the foregoing discussion of the problem of futility. Fainting obliterates only the awareness of the threat. Although it might deceive, and thereby possibly thwart, an attacking animal by making the object of its attack appear dead, in other cases it does nothing to remove the threat. Rather, it may leave the one who faints totally vulnerable, unable to resist in any way or to escape from the threat. The consequences here may be the opposite of the safety and security sought. The waiter seems to be in a similar position, inasmuch as his robot-like behavior is and will remain antithetical to what he sought: the more he becomes object-like, the less he is the subjectivity-as-object he sought to become.

The opposition between the goals and the actual consequences of actions makes apparent the moral problem with bad faith, namely, that those in bad faith try to will the end without willing the means. In this sense, consequences can count against an individual's actions and choices although, given the ultimate futility of human actions, consequences can never justify the value of any other actions and choices.

What this analysis of consequences means, then, is that Sartre can affirm a particular way of playing as that appropriate to the authentic individual. Such

${ }^{19}$ Sartre, Cahiers pour une morale, pp. 180, 451, 175, 216.

${ }^{20}$ Sartre, The Emotions, trans. Bernard Frechtman (New York: Philosophical Library, 1948), pp. 62-63. 
individuals accept and affirm the futility of their efforts to actualize their ultimate goal; yet they continue to do what they can to accomplish it. In Iron in the Soul, for example, Mathieu recognizes the futility of his action and impending death-that ambushing those particular Nazi soldiers will "merely put their time-table out by ten minutes! "21

Individuals like Hoederer (Dirty Hands) and Genet (Saint Genet) acknowledge and accept their freedom and the ultimate futility of their actions, yet enter the fray, resolved to control and change what they can. Although they may neither control nor change the course of history, nevertheless they act. They realize their finitude and essential ambiguity and work within these even while striving toward an impossible goal. Mathieu sums up this attitude as he indicts himself and a cohort for their previous political noninvolvement. Implicitly recognizing that their participation in politics might not have prevented the present confrontation, he still affirms: "At least you would have done all you could. ${ }^{22}$ As Sartre says in Cahiers pour une morale:

The historical agent ought to accept that his work prolongs itself only by proposition and that the spirit which animates it will continue to act only in the manner of a residue. But at the same time, he ought to take all precautions to retard as long as possible the moment of alienation. ${ }^{23}$

\section{Play as Revolutionary Activity}

Finally, the revolutionary possibilities of play should not be ignored. Virginia Woolf hinted at these when she observed the revolutionary potential of women's laughter and their turning away from the all-too-serious pomp and circumstance of those in positions of power. ${ }^{24}$ Play, like laughter and turning

\footnotetext{
${ }^{21}$ Sartre, Iron in the Soul, Irans. Gerard Hopkins (Harmondsworth, Middlesex: Penguin Books, 1971), p. 222.

${ }^{22}$ Ibid., p. 87.

${ }^{23}$ Sartre, Cahiers pour une morale, p. 54.

${ }^{24}$ Virginia Woolf, Three Guineas (New York: Harcourt Brace Jovanovich, 1938), pp. 19-21, 150.
} 
away, involves a disconnection from the seriousness of those for whom values are given and not created. The playful individual "makes light" of those values, indeed of all values, by recognizing freedom as their ultimate foundation.

The obvious danger of such playfulness, of course, is that play, like anger, requires what Marilyn Frye calls "uptake," though perhaps not in quite the same way. At least, play, like anger, requires uptake if it is to be revolutionary, if it is to make any difference vis-à-vis the structures and activities of oppression. Just as Frye recognizes that a woman's anger at a car mechanic may simply be dismissed as "crazy,"25 so, too, may the playful treatment of serious and oppressive values by the oppressed be regarded as mad or childlike. Or it may just be ignored.

Even when the play is noticed and recognized for what it is, it is all too likely to be only momentarily unsettling, a dis-ease for the serious that is quickly replaced by the familiar and, for them, comfortable values and order of the ordinary. In fact, and far more dangerous, this temporary unsettling may by used by the forces of oppression as a safety-valve for the purpose of releasing tensions in the oppressed and even as a means of relieving misgivings in the oppressors themselves. If everyone leaves the playful activity with a sense of distance from and moral superiority to the oppressive values embedded in the social structures, then those structures have been reinforced rather than challenged by the play. Such play is clearly part and parcel of the status quo and not a revolutionary force against it.

Mikhail Bakhtin points to both the revolutionary potential and the reactionary uses of play in his discussion of carnival. Although he is interested in the "carnival sense of the world" embodied in some literature, he recognizes that carnivals are a primary locus in real life of this spirit with its characteristic "atmosphere of joyful relativity." In the carnival, as he says, ". . . life is drawn out of its usual rut, it is to some extent 'life turned inside out,' 'the reverse side of the world'. . . " The "laws, prohibitions, and restrictions that determine the structure and order of ordinary, that is noncarnival, life are suspended during carnival." This means, he says, "what is suspended first of all is hierarchical structure and all the forms of terror, reverence, piety, and etiquette connected with it-that is, everything resulting from socio-hierarchical inequality or any

\footnotetext{
${ }^{25}$ Marilyn Frye, "A Note on Anger," The Politics of Reality: Essays in Feminist Theory (Trumansburg, NY: The Crossing Press, 1983), pp. 88-89.
} 
other form of inequality among people (including age)." In other words, "[a]ll distance between people is suspended, and a special carnival category goes into effect: free and familiar contact among people. ${ }^{26}$ During such festivals, "all participants entered, as it were, the utopian kingdom of absolute equality and freedom," albeit only for a "strictly limited" time. ${ }^{27}$

Carnival life sounds very like a temporary embodiment of the kingdom of ends where each may, as Sartre says, appeal to everyone else for aid and where oppressive hierarchies are abolished. In fact, Sartre himself suggests something like this in his description of festival as "liberation from the spirit of seriousness, the expenditure of economics, the ruin of hierarchy, and the absorption of the other by the Same, of the objective by intersubjectivity, of order by disorder. ${ }^{28}$

Although carnival or festival may unsettle hierarchy and the spirit of seriousness, for the revolutionary, at least, something important is missing. What is missing is lasting effect on society and on its oppressive hierarchies. As Bakhtin observes, carnival is a form of ritual laughter, and such laughter is always linked with death and rebirth. Earthly authorities are ridiculed and put to the test in order "to force them to renew themselves. ${ }^{29}$ Unless the authorities are totally unbending and unwilling to make even the most minor of concessions, such renewal favors and strengthens the status quo rather than challenging it in any really fundamental way. When the carnival ends, oppressive hierarchies are not substantially weakened but rather are purified and even strengthened by having endured the challenge. Thus, it would seem, they are more firmly entrenched than ever.

One problem with real carnival is that it is ritual. As ritual, the carnival is removed from real life. De Beauvoir notes this problem when she says, "The

\footnotetext{
26 Mikhail Bakhtin, Problems of Dostoevsky's Poetics, trans. Caryl Emerson (Minneapolis: University of Minnesota Press, 1984), pp. 107, 122-23.

${ }^{27}$ Bakhtin, Rabelais and His World, trans. Helene lswolsky (Bloomington: Indiana University Press, 1984), pp. 264-65.

${ }^{28}$ Sartre, Cahiers pour une morale, p. 388.

${ }^{29}$ Bakhtin, Problems of Dostoevsky's Poetics, p. 127.
} 
moment of detachment, the pure affirmation of the subjective present are only abstractions; the joy becomes exhausted, drunkenness subsides into fatigue, and one finds himself with his hands empty because one can never possess the present: that is what gives festivals their pathetic and deceptive character. ${ }^{n 30}$

In addition, the carnival is not only separate from real life but also, as a ritual, it has a clearly demarcated beginning and end. Part of what allows the sense of playfulness such license, even for those in power, is that everyone knows the carnival will end and something very like business as usual will take its place. Some features of that business may change as a result of the carnival, but everyone can be assured that its fundamental aspects will not change and that all will generally be in the same hierarchical power arrangements once again. Commoners may be treated momentarily as kings and vice versa, but there is little chance that the hilarity of the moment will permanently result in any such displacement.

Finally, real carnival frequently does not achieve the liberation of which its laughter is capable, according to Bakhtin, because it may lack the awareness necessary for it to express "a critical and clearly defined opposition." Without sufficient awareness, individuals and periods, like the Middle Ages, may allow to exist in their consciousness "side by side but never merg[ing]" both "the serious and the laughing aspect[s]" of the world, both the official and the carnival, both the pious and the grotesque. With awareness, Bakhtin believes, laughter can liberate "not only from external censorship but first of all from the great interior censor; it liberates from the fear that developed in man during thousands of years: fear of the sacred, of prohibitions, of the past, of power." Thus, he says: "[I]t unveils the material bodily principle in its true meaning. Laughter opened men's eyes on that which is new, on the future." In this way, over time, laughter helped transform "old truth and authority into a Mardi Gras dummy, a comic monster that the laughing crowd rends to pieces in the marketplace. ${ }^{n 31}$

What we learn about the revolutionary potential of carnival, then, is both positive and negative. Positively, carnival can be seen as providing an embodiment of sorts, however temporary, of something like the kingdom of

\footnotetext{
${ }^{30} \mathrm{de}$ Beauvoir, The Echics of Ambiguity, pp. 126-27.

${ }^{31}$ Bakhtin, Rabelais and His World, pp. 96, 94, 213.
} 
ends. It offers a vision of the way play can unsettle oppressive hierarchies and create an openness otherwise seldom experienced. Also, it provides a way for an individual to liberate himself or herself from the hold of externally imposed and serious values.

At the same time, though, we learn what play cannot be if it is to be truly revolutionary, that is, if it is to disrupt the structures upholding those values. In particular, we see the dangers of a ritualized play, one that is not ongoing and that has not developed its awareness into clear opposition. Such play, while mocking and temporarily unsettling the status quo, is ultimately no challenge to it, indeed is quite likely to strengthen it by serving as a safety valve, providing harmless release even for potentially quite disruptive tensions in the society.

From these accounts of carnival and festival, I conclude, certain conditions must be met if play's revolutionary potential is to be realized. First and foremost, it must emerge from clear, critical, and oppositional awareness. This condition is essential if the activity is to achieve even the players' liberation from internalized censors, much less the disruption of institutionalized structures of oppression.

If the activity is to have any chance of unsettling the status quo, other conditions must be met as well. Thus, a second condition is that the playful activity be able to get itself recognized as play. Oppressed groups no doubt will have great difficulty with this condition inasmuch as their activity is likely to be characterized from the outset as child- or animal-like and they themselves as somewhat simple-minded. In such circumstances, even open caricature of the serious rules, regulations, and behavior will generally be taken as worshipful imitation rather than as joyful relativizing of the serious.

Third, the play must not serve as a safety valve within the structure of the status quo; in other words, it must not provide an unthreatening venting of tensions that might otherwise erupt and seriously disrupt existing oppressive structures. Given the tendency of the status quo to co-opt all antagonists and challenges, revolutionary play will have difficulty meeting this condition.

Finally, if play is to be revolutionary, it must be ongoing. As long as it has a clearly delineated and anticipated beginning and end separating it from the rest of life, it will not ultimately disrupt and can safely be indulged to break the monotony, to vent discontent, and to show how strong the present system is. Thus, to be effective as a revolutionary strategy, play must catch people off guard. It must occur at inopportune moments. 
To clarify the last of these conditions, Kierkegaard's method of indirect discourse may be instructive. Kierkegaard's strategy was to play the role of idler to the hilt and (albeit somewhat transparently) to "hide" behind pseudonyms so that his words would catch the reader unaware and affect her or him before rationalizations and other defenses could be constructed. His models for such discourse include the Old Testament prophet Nathan who told King David a story concerning an individual whose behavior paralleled David's "taking" of Bathsheba from her husband Uriah. When David responded with outrage against the individual in the story, Nathan looked at David and said, "Thou art the man."

Although Kierkegaard's behavior as he plays the idler is itself playful and his words supposedly are designed to turn his hearers within themselves, to make them aware of themselves as individuals and of their freedom, his use of play remains too much in the arena of individual solutions for it to be useful as a revolutionary model. Although his method would undercut seriousness, his goal was to turn his audience into lonely individuals, not to undermine an oppressive status quo. If play is to be revolutionary, it must reverse the model offered by Kierkegaard. Instead of playing the idler or buffoon, the revolutionary player would probably do better generally to appear to be as ordinary as possible so that intermittent and irreverent mocking of the ordinary has the greatest possible unsettling effect.

Various mocking strategies have been proposed. Luce Irigaray, according to Rosemarie Tong, suggests exaggeration. Recognizing that women exist as images in men's eyes, she proposes that women ". . . take those images and reflect them back to men in magnified proportions. " By overdoing these images she hopes to effect their undoing. This strategy is not without its perils since, as she recognizes, "[ $t]$ he distinction between mimicking the patriarchal definition of woman in order to subvert it and merely fulfilling this definition is not clear. ${ }^{32}$ This seems especially problematic given that we live in a society where images, particularly those of women, offered by Hollywood, by the media, and by religious fundamentalism are frequently so extreme that it is difficult to conceive of further magnification. While feminists would no doubt find it jolting to encounter a real-life Gone with the Wind Mammy or heavybreathing Marilyn Monroe sex-goddess, it would probably take a lot to

\footnotetext{
${ }^{32}$ Tong, Feminist Thought (Boulder, Colorado: Westview Press, 1989), pp. 228-29.
} 
"magnify" the "proportions" in those images and probably a lot more to achieve the effect for which Irigaray hopes. A culture constantly fed such caricatures seems far likelier to respond approvingly to real-life embodiments thereof, even exaggerated ones, if such are possible. However, the feminist activist/comedy group Ladies Against Women (LAW) seems to be exploring creatively the possibilities of mocking through playful exaggeration, with the motto "I'd rather be ironing," signs like "My home is his castle," "Sperm are people, too," and chants like "Hit us again, harder, harder!" The effects of these on women may be generally salutary, but it remains to be seen if such play can significantly unsettle the views being lampooned.

A thought-provoking suggestion comes from Michèle Le Doeuff. In discussing her childhood passion for Shakespeare- "especially for the characters of the fools"-she confesses that she wished to be either Feste or King Lear's Fool when she grew up, a vocation she gave up when she realized that "life is not as well written as it would have been if Shakespeare had taken charge of it." In philosophy, she later found something similar to the "language of fools," something very close to "their sarcastic and corrosive utterances, their unseasonable taste for truth without pomposity, their corruption of words and their art of impertinence which forces authority, sometimes royal authority, to enter into their irony. . . ." This "foolery," she found, was compatible with life as it existed outside of Shakespearean plays, was open even to women, and was completely at odds with the respect for academic hierarchy and the great authors with which academicians had replaced "Socrates' irreverence." Later, she mentions approvingly a statement worn by some French feminists, roughly equivalent to "'We do not dare to be ridiculous enough, and it may kill us.' " 33

This emphasis on foolery and the ridiculous seems to connect with Le Doeuff's method, a method of exposure and ridicule - "to show that where women are concerned the learned utter, and institutions let them utter, words which fall clearly below their own usual standards of validation. ${ }^{34}$ While this strategy is that of a worthwhile and philosophically sound project, relatively few men are likely to feel the bite of her mocking exposure. The "academicism" to

\footnotetext{
${ }^{33}$ Michèle Le Doeuff, Hipparchia's Choice: An Essay Conceming Women, Philosophy, etc, trans. Trista Selous (Cambridge, MA: Blackwell, 1991), pp. 9-10, 85.

${ }^{34}$ Ibid., p. 37.
} 
which she points is so firmly entrenched that such irreverence, particularly when it comes from women, is usually ignored or dismissed.

Tong cites Dorothy Dinnerstein's recognition that "women have played the part of court jesters, poking fun at the games men play; and women's irreverence has served to release the tension that ripples through the world of enterprise." Because of this release of tension, "things have never seemed bad enough for us to change the course of history. ${ }^{35}$ In fact, women's irreverence seems, to many men, nothing more than lightheartedness, a necessary antidote to their own seriousness. Thus, women's irreverence alone is clearly not enough. Only if it is relentlessly unexpected and inappropriate (thereby satisfying the last condition) does it stand any chance at all of unsettling, and then probably only a small one. Very likely, such play is more useful for developing the morale and vision of the players than it is for changing oppressive institutions and those who seriously uphold them.

Even though the revolutionary potential of play is likely to be more indirect than direct, nonetheless that potential together with its other functions renders it very significant for those who are trying to relate in non-oppressive ways. Hoagland offers one compelling example of play within community when she discusses the importance of clowns in Anne Cameron's Daughters of Copper Woman. Reminiscing about her Indian community "in the days before the invaders came," Granny observes that clowns, ideally without meanness or hostility, were needed and used "to help us all learn the best ways to get along with each other." By simply mimicking the serious gestures of others, clowns enabled people to see themselves as others see them, an important selfrecognition apparently made more forceful by the means of presentation. Even a clown would occasionally find another clown in tow: "Sometimes a clown would find another clown taggin' along behind, imitatin', and then the first one knew that maybe somethin' was gettin' out of hand, and maybe the clown was bein' mean or usin' her position as a clown to push people around and sharpen her own axe for her own reasons. ${ }^{36}$

\footnotetext{
${ }^{35}$ Tong, Feminist Thought, p. 161.

${ }^{36}$ Anne Cameron, Daughiers of Copper Woman (Vancouver, B. C.: Press Gang Publishers, 1981), p. 110.
} 
Moreover, as Maria Lugones recognizes, play provides a bridge for individuals whose "worlds" are quite different. Access to one another, absolutely necessary for understanding and communication, is barred to the serious, to those who would uphold the rules of the status quo, to those who would conquer. Only those who are open to being fools, who do not worry about competence and self-importance, who reject norms as sacred, and who delight in ambiguity, can understand what it is to be someone quite different and what it is to be ourselves in that individual's eyes. ${ }^{37}$

Such " "world'-travelling" is essential for those who oppose oppression in all of its ramifications. On the one hand, it is an unavoidable step in the understanding of oppression since without it one continues to participate in the structures of dominance and oppression by forcing the reality and experiences of others into limited frameworks which are applied to others with an arrogance like that of the dominant, an arrogance which one may resist but at the same time perpetuate. On the other hand, playful "world'-travelling" continually reveals to us and keeps us open to the complexity of the other with whom we wish to share a world in which each is respected as an end and in which each can appeal to all the others.

Finally, if nothing else, as Anne Tristan and Annie de Pisan observe, the laughter connected with revolutionary activity adds a note of levity and joy and thereby does change the world, making it a little less dismal, a little less sinister, introducing a politics not itself "as sad and sorry an affair as everything else. ${ }^{.38}$ Such a change, indeed, may be vital if revolutionaries are to be able to keep before themselves the ideal society toward which they work and to see intimations of their ideal, however small, in their accomplishments. As long as such change is not mistaken for change in the objective structures of oppression, laughter is an important part of revolution.

${ }^{37}$ Maria Lugones, "Playfulness, 'World'-Travelling, and Loving Perception," Hypatia, Vol. 2, No. 2 (Summer 1987), pp. 15-17.

${ }^{38}$ Anne Tristan and Annic de Pisan, "Tales from the Women's Movement," French Feminist Thought: A Reader, ed. Toril Moi (New York: Basil Blackwell Inc., 1987), p. 67. 


\section{Conclusion}

While play is vital to those who try to free themselves and others from seriousness and from the oppressive structures maintained by such, it is important to note that play may accomplish much more. Not only does play offer players a way to achieve distance from the seriously-held oppressive values of the status quo, but also it enables those who play at least momentarily to glimpse a kingdom of ends where the freedom of everyone is acknowledged and where oppressive hierarchies are undone. In addition, play, as we have seen, resolves some serious problems confronted by an ethics of freedom vis-à-vis relativism and futility. Even though it has limited potential as a revolutionary strategy, play is nonetheless vital to ethics. 